\title{
ARTICLE III LIMITS ON STATUTORY STANDING
}

\author{
JOHN G. ROBERTS, JR. $\dagger$
}

Henry James wrote that "[w]e must grant the artist his subject, his idea, his donee: our criticism is applied only to what he makes of it." Dean Nichol and Professor Pierce lose sight of this principle in their criticism of Justice Scalia's opinion for the majority in Lujan $v$. Defenders of Wildlife. ${ }^{2}$ One of the "donees"- the givens-in Defenders was that injury in fact is required for standing under Article III. The Court's precedents so hold, ${ }^{3}$ and none of the parties before the Court disputed the proposition. It certainly is fair to challenge this premise, and also fair to challenge the reasoning of the opinion in light of the premise. What strikes me as a bit above the odds, however, is challenging the reasoning of the opinion in light of a different premise-the premise that injury is not an Article III requirement. The result is somewhat like criticizing a person for speaking awful French, only to discover that he was in fact speaking fluent Spanish. Defenders is a sound and straightforward decision applying the Article III injury requirement. The fact that it fails as

† Partner, Hogan \& Hartson, Washington, D.C. The author served as Principal Deputy Solicitor General, United States Department of Justice, 1989-1993.

The Office of the Solicitor General represented Secretary of the Interior Manuel Lujan before the U.S. Supreme Court in Lujan v. Defenders of Wildlife, 112 S. Ct. 2130 (1992), and the author argued Lujan v. National Wildlife Fed'n, 497 U.S. 871 (1990), on his behalf.

This Comment is based on remarks presented at a symposium on Lujan v. Defenders of Wildlife held at Duke University School of Law on January 21, 1993.

1. Henry James, The Art of Fiction, in The PORTABle Henry JAMES 387, 402-03 (Morton D. Zabel ed., 1968).

2. 112 S. Ct. 2130 (1992).

3. See, e.g., Whitmore v. Arkansas, 495 U.S. 149, 155 (1990) ("To establish an Art. III case or controversy, a litigant must first clearly demonstrate that he has suffered an 'injury in fact.' "); Allen v. Wright, 468 U.S. 737, 750-51 (1984); Valley Forge Christian College v. Americans United for Separation of Church \& State, 454 U.S. 464, 471-76 (1982). 
an application of some other, non-constitutional concept of injury Dean Nichol prefers should come as no surprise.

Before considering whether Defenders is "a transformation in the law of standing" that is "inconsistent with the principle of judicial restraint," it may be worthwhile to recall that the Supreme Court for some time has recognized standing as a constitutionally based doctrine designed to implement the Framers' concept of "the proper-and properly limited-role of the courts in a democratic society." The legitimacy of an unelected, lifetenured judiciary in our democratic republic is bolstered by the constitutional limitation of that judiciary's power in Article III to actual "cases" and "controversies." The need to resolve such an actual case or controversy provides the justification not only for judicial review over the popularly elected and accountable branches of the federal government, ${ }^{7}$ but also for the exercise of judicial power itself, "which can so profoundly affect the lives, liberty, and property of those to whom it extends." This is nothing new; the Court explained a century ago that the exercise of federal judicial power was legitimate only "as a necessity in the determination of real, earnest, and vital controversy."

One way federal courts ensure that they have a "real, earnest, and vital controversy" before them is by testing the plaintiff's standing to bring suit. The plaintiff must allege at the pleading stage, ${ }^{10}$ and later prove, ${ }^{11}$ an injury that is fairly traceable to the defendant's challenged conduct and that is likely to be redressed by the relief sought. ${ }^{12}$ If the plaintiff cannot do so, the court must dismiss the case as beyond its power to decide-no matter

4. Gene R. Nichol, Jr., Justice Scalia, Standing, and Public Law Litigation, 42 DUKE L.J 1141, 1142 (1993).

5. Richard J. Pierce, Jr., Lujan v. Defenders of Wildlife: Standing As a Judicially Imposed Limit on Legislative Power, 42 DUKE L.J. 1170, 1200 (1993).

6. Allen, 468 U.S. at 750 (quoting Warth v. Seldin, 422 U.S. 490, 498 (1975)); see Valley Forge, 454 U.S. at 471-76.

7. See Marbury v. Madison, 5 U.S. (1 Cranch) 137 (1803).

8. Valley Forge, 454 U.S. at 473.

9. Chicago \& Grand Trunk R.R. v. Wellman, 143 U.S. 339, 345 (1892), quoled in Valley Forge, 454 U.S. at 471. 501.

10. See, e.g., Pennell v. City of San Jose, 485 U.S. 1, 7 (1988); Warth, 422 U.S. at

11. Lujan v. National Wildlife Fed'n, 497 U.S. 871,883 (1990); Warth, 422 U.S. at 501; United States v. SCRAP, 412 U.S. 669, 689 (1973).

12. Allen v. Wright, 468 U.S. 737, 751 (1984); Valley Forgc, 454 U.S. at 472. 
when in the litigation the flaw is discovered or arises. ${ }^{13} \mathrm{~A}$ dismissal on the basis of standing prevents the court from reaching and deciding the merits of the case, whether for the plaintiff or the defendant. Standing is thus properly regarded as a doctrine of judicial self-restraint. ${ }^{14}$

The Defenders Court engaged in just such an exercise of judicial self-restraint, soundly based on precedent. The Court concluded that the plaintiff had failed to prove injury in fact ${ }^{15}$ hardly a surprising result under the Court's standing precedents, given the vague and amorphous nature of the plaintiff's claims of injury. The Court then concluded that Congress nonetheless intended the plaintiff to have a right to sue under the statute in question. ${ }^{16}$ Although I regard this ruling as more problematic, ${ }^{17}$ the conclusion that so surprises Dean Nichol and Professor Pierce-that the Endangered Species Act is therefore unconstitutional as applied to this particular plaintiff in this particular lawsuit-follows inexorably, and is no less an act of judicial selfrestraint than any other dismissal on the basis of standing.

Dean Nichol first faults the Court for failing to overturn established precedent and rule that injury in fact is not, after all, a requirement of Article III. According to Dean Nichol, James Madison's statement that the federal courts would be limited to matters of "a Judiciary nature"18 was "obviously circular," and historical scholarship has shown that the injury requirement is not constitutionally based. ${ }^{19}$ A response to the historical scholarship is beyond the scope of this Comment. ${ }^{20}$ The Framers recognized

13. Bender v. Williamsport Area Sch. Dist., 475 U.S. 534, 546 (1986); cf. Gwaltney of Smithfield, Ltd. v. Chesapeake Bay Found., 484 U.S. 49, $66-67$ (1987) (analyzing development of lack of standing during pendency of case in terms of mootness).

14. See United States v. Richardson, 418 U.S. 166, 188 (1974) (Powell, J., concurring) ("Relaxation of standing requirements is directly related to the expansion of judicial power."). This point is true whether or not the standing decision is correct in any particular case. If a court errs in its standing dismissal and should have reached the merits, that court is wrong - not activist.

15. Lujan v. Defenders of Wildlife, 112 S. Ct. 2130, 2138 (1992).

16. Id. at 2145 .

17. See infra text accompanying notes $49-53$.

18. 2 RECORDS OF THE FEDERAL CONVENTION of 1787, at 430 (Max Farrand ed., 1966).

19. Nichol, supra note 4 , at $1150-52$.

20. I would note, however, that Dean Nichol's confidence in the constitutionality of qui tam actions is not universally shared. The question is currently pending before the 
that legislative, executive, and judicial functions were not divided into hard and fast categories, but, as Justice Scalia noted in Defenders, the "landmarks" defining the tasks of the judiciary are "less uncertain" than those delimiting the responsibilities of the other branches. ${ }^{21}$ There are landmarks-the inquiry is not circular.

In any event, the objection to the Court's refusal to abandon injury as an Article III element of standing is a curious one in a discussion otherwise critical- of supposed judicial activism. The Court has recognized the constitutional nature of the injury requirement for some time, certainly before Justice Scalia's appointment to the Supreme Court. ${ }^{22}$ As Dean Nichol notes, the academic community is less convinced, ${ }^{23}$ but the Court is firmly committed. No party before the Court in Defenders suggested

U.S. Court of Appeals for the Ninth Circuit. United States ex rel. Madden v. General Dynamics, No. CV-88-05352-WMB (C.D. Cal. filed Sept. 6, 1988), petition for permission to appeal granted, No. 92-56042 (9th Cir. Aug. 26, 1992); United States ex rel. Kelly v. The Boeing Co., No. CV-89-1732-R (W.D. Wash. filed Nov. 30, 1989), petition for permission to appeal granted, No. 92-3660 (9th Cir. Sept. 11, 1992). The Office of Legal Counsel of the U.S. Department of Justice has formally opined that such actions are unconstitutional. See Constitutionality of the Qui Tam Provisions of the False Claims Act, 13 Op. Off. Legal Counsel 249 (1989) (preliminary print). In any event, reliance on "the business of the Colonial courts and the courts of Westminster when the Constitution was framed," .Nichol, supra note 4, at 1151 (quoting Joint Anti-Fascist Refugee Comm. v. MeGrath, 341 U.S. 123, 150 (1951) (Frankfurter, J., concurring)), must be tempered with a recognition that the Framers were moving from a unitary system of government to one of separated powers, a move with consequences for the judiciary as well as for the other branches of government. Practice prior to the framing of the Constitution-and perhaps constitutionally dubious remnants persisting thereafter-thus is not an infallible guide to the scope of judicial power under Article III. See Valley Forge Christian College v. Ainericans United for Separation of Church \& State, 454 U.S. 464, 471 (1982) ("The requirements of Art. III are not satisfied merely because a party requests a court of the United States to declare its legal rights, and has couched that request for forms of relief historically associated with courts of law in terms that have a familiar ring to those tramed in the legal process.").

21. Lujan v. Defenders of Wildlife, 112 S. Ct. 2130, 2136 (1992).

22. See Paul M. Bator et aln, Hart and Wechsler's The Federal Courts AND THE FEDERAL SYSTEM 123 (3d ed. 1988) ("The cases have long accepted the principle that Article III itself requires the plaintiff to show that he was injured by the conduct under challenge.").

23. Nichol, supra note 4, at 1151-52; see, e.g., Raoul Berger, Standing to Sue in Public Actions: Is It a Constitutional Requirement?, 78 YALE L.J. 816, 839 (1969); Louis L. Jaffee, The Citizen as Litigant in Public Actions: The Non-Hohfeldian or Ideological Plaintiff, 116 U. PA. L. REv. 1033, 1044 (1968); Cass R. Sunstein, Standing and the Privatization of Public Law, 88 ColUM. L. REv. 1432, 1474-80 (1988); Steven L. Winter, The Metaphor of Standing and the Problem of Self-Govermance, 40 STAN. L. REv. 1371, 1395-96 (1988). 
abandoning the requirement. It certainly would have been an extraordinary adventure in judicial activism for the Court suddenly to change directions, overrule numerous precedents, and announce, uninvited, that it no longer regarded the injury requirement as an Article III restriction.

Dean Nichol's next criticism is, like the foregoing one, more a criticism of the Court's standing jurisprudence in general than of the Defenders opinion in particular. Invoking Hindu philosophy and Nietzsche, he notes that the task of defining injury is "amorphous, complex, and value-laden."24 Although it is easier to define injury in some cases than in others, the occasional difficulty of the enterprise is hardly reason to abandon it altogether-to throw up one's hands and announce that an injury standard "can have no ascertainable meaning."25 As the Court has explained, "[t]he absence of precise definitions ... hardly leaves courts at sea in applying the law of standing." 26 As is the case whenever the Court defines a legal requirement, "the standing concepts have gained considerable definition from developing case law."27 A lawyer looking at that caselaw will learn that the injury must be "distinct and palpable,"28 "concrete,"29 "certainly impending,",30 "real and immediate,"31 and "actual or imminent, not "conjectural' or 'hypothetical." "32 To be sure, these are not objectively verifiable, self-defining terms in some philosophical sense. They are, however, reasonably precise guidelines of the sort common to the lawyer's craft.

As the Court has explained, any effort to flesh out the concept of injury and other standing principles must be based on "reference to the Art. III notion that federal courts may exercise power 'only in the last resort, and as a necessity,' and only when

24. Nichol, supra note 4 , at $1154-55,1157$.

25. Id. at 1157-58.

26. Allen v. Wright, 468 U.S. 737,751 (1984).

27. Id.

28. Gladstone, Realtors v. Village of Bellwood, 441 U.S. 91, 100 (1979) (quoting Warth v. Seldin, 422 U.S. 490,501 (1975)).

29. Schlesinger v. Reservists Comm. to Stop the War, 418 U.S. 166, 176-78 (1974).

30. Babbitt v. United Farm Workers, 442 U.S. 289, 298 (1979).

31. City of Los Angeles v. Lyons, 461 U.S. 95, 101-02 (1983); O'Shea v. Littleton, 414 U.S. 488,494 (1974).

32. Whitmore v. Arkansas, 495 U.S. 149, 155 (1990) (quoting Lyons, 461 U.S. at 101-02). 
adjudication is "consistent with a system of separated powers and [the dispute is one] traditionally thought to be capable of resolution through the judicial process." "33 Dean Nichol greets this enterprise with skepticism, but that is to be expected given his view that the injury requirement is not found in Article III in the first place. The need to insist upon meaningful limitations on what constitutes injury for standing purposes-regardless of what the Hindus or Nietzsche have to say about it-flows from an appreciation of the key role that injury plays in restricting the courts to their proper function in a limited and separated government. ${ }^{34}$ If you do not recognize that role-if you think, as Dean Nichol does, that the Framers were being "obviously circular" when they "generally supposed" that the jurisdiction of the federal courts "was constructively limited to cases of a Judiciary nature"35 - then you will fail to understand why the concept of injury must be delimited and therefore not appreciate the principle guiding the Court's developing caselaw.

The conclusion that the plaintiff in Defenders failed to satisfy the basic Article III requirement of showing injury in fact followed from the Court's prior precedents. ${ }^{36}$ The only concrete and specific showing of injury made by Defenders of Wildlife was that, years before, two of its members had visited areasspecifically, the habitats of the Nile crocodile and Asian leopard-allegedly affected by funded projects. Since the plaintiff sought prospective relief, not damages, any past injury arising from these visits was insufficient to establish standing. ${ }^{37}$ As to the future injury, the affiants could claim no more than that they desired to revisit the areas at some point and were concerned that

33. Allen v. Wright, 468 U.S. 737, 752 (1984) (citations omilted).

34. See Center for Auto Safety v. Thomas, 847 F.2d 843, 883 (D.C. Cir.) (en banc) (Silberman, J.) (" $[\mathrm{W}] \mathrm{e}$ must be careful to delineate the 'distinct and palpable' injury suffered lest we turn the injury component of Article III into a paper barrier and thereby convert the federal judiciary into a referee of political disputes."), reh'g granted and opinion vacated, 856 F.2d 1557 (D.C. Cir. 1988).

35. 2 RECORDS, supra note 18, at 430; see Nichol, supra note 4, at 1150.

36. I agree with Professor Pierce's discussion of the treatment of standing based on "procedural injury" in the inajority opinion. Pierce, supra note 5, at 1184-86. Indeed, the plaintiff in Defenders did not even press a claim of standing based solely on such an injury, apart from the claimed injury in fact. See Respondent's Brief at 35 n.10, Petitioners' Reply Brief at 2, Lujan v. Defenders of Wildlife, 112 S. Ct. 2130 (1992) (No. 90-1424).

37. See City of Los Angeles v. Lyons, 461 U.S. 95, 106 n.7 (1983). 
if the pertinent federal agencies failed to consult as required by the Endangered Species Act, they might suffer harm-that is, an absence of Nile crocodiles or Asian leopards-were they to return. This is precisely the sort of "conjectural" or "hypothetical" harm the Court has held to be insufficient to establish standing. ${ }^{38}$ As the Court has explained, "[a]llegations of possible future injury do not satisfy the requirements of Art. III." ${ }^{\prime 39}$

Perhaps recognizing this difficulty, Professor Pierce argues that "the Court should not require evidentiary proof of particularized injury as a prerequisite to judicial review of all agency actions," 40 and surmises that "[a]t any given point in time, many people have specific plans to visit the habitat of the Nile crocodile and the Asian leopard, and most would be happy to submit an affidavit as a member of Defenders of Wildlife." ${ }^{41}$ I am not as sure about the latter point as Professor Pierce is; if there really are "many people" with such specific plans who are members of the plaintiff's organization, it is not unreasonable to wonder why the organization relied on such weak affidavits. More importantly, the Supreme Court has emphasized that "[i]t will not do to 'presume' the missing facts" needed to establish standing. ${ }^{42}$ As the Court has frequently reiterated, standing allegations "must be true and capable of proof at trial;",43 it is not enough to rest on the pleadings. "It is a long-settled principle that standing cannot be 'inferred argumentatively from averments in the pleadings,'... but rather 'must affirmatively appear in the record." "45 Standing is, after all, a constitutional requirement. Assuming standing on the basis of the pleadings would be tantamount to assuming Article III jurisdiction. The proper approach is just the

38. Whitmore v. Arkansas, 495 U.S. 149, 155 (1990).

39. Id. at 158.

40. Pierce, supra note 5 , at $1175-76$.

41. Id. at 1177.

42. Lujan v. National Wildlife Fed'n, 497 U.S. 871,889 (1990).

43. United States v. SCRAP, 412 U.S. 669, 689 (1973).

44. See National Wildlife Fed'n, 497 U.S. at 889; Gwaltney of Smithfield, Ltd. v. Chesapeake Bay Found., 484 U.S. 49, 66 (1987); Warth v. Seldin, 422 U.S. 490, 501-02 (1975); see also Land v. Dollar, 330 U.S. 731, 735 n.4 (1947) ("When a question of the District Court's jurisdiction is raised, ... the court may inquire, by affidavits or otherwise, into the facts as they exist.").

45. FW/PBS, Inc. v. City of Dallas, 493 U.S. 215, 231 (1990) (quoting Grace v. American Central Ins. Co., 109 U.S. 278, 284 (1883); Mansfield C. \& L.M.R. Co. v. Swan, 111 U.S. 379, 382 (1884)). 
opposite-to "presume that federal courts lack jurisdiction 'unless "the contrary appears affirmatively from the record." ",46

Dean Nichol's proposed solution to the occasional difficulties in defining injury-that is, leaving it to Congress-could only come from one who, like Dean Nichol, does not regard this as a constitutional problem in the first place. If, as the Court has repeatedly reiterated, the standing requirement is a constitutional limitation on the jurisdiction of the federal courts, it is a limitation that Congress as well as the courts must respect. The Court has said so in the plainest possible terms:

Congress may, by legislation, expand standing to the full extent permitted by Art. III, thus permitting litigation by one "who otherwise would be barred by prudential standing rules." In no event, however, may Congress abrogate the Art. III minima: A plaintiff must always have suffered "a distinct and palpable injury to himself," that is likely to be redressed if the requested relief is granted. ${ }^{47}$

If Congress directs the federal courts to hear a case in which the requirements of Article III are not met, that Act of Congress is unconstitutional. Defenders is apparently the first Supreme Court case to so hold because of lack of Article III standing, ${ }^{48}$ but the conclusion that Article III limits congressional power can hardly be regarded as remarkable.

46. Renne v. Geary, 111 S. Ct. 2331, 2336 (1991) (quoting Bender v. Williamsport Area Sch. Dist., 475 U.S. 534, 546 (1986); King Bridge Co. v. Otoe County, 120 U.S. 225, 226 (1887)).

47. Gladstone, Realtors v. Village of Bellwood, 441 U.S. 91, 100 (1979) (quoting Warth, 422 U.S. at 501); see also Valley Forge Christian College v. Americans United for Separation of Church \& State, 454 U.S. 464, 488 n.24 (1982) ("Neither the Administrative Procedure Act, nor any other congressional enactment, can lower the threshold requirements of standing under Art. III.").

48. At least Defenders is the first holding to be accompanied by an opinion. The three-judge district court in McClure v. Carter, 513 F. Supp. 265 (D. Idaho), affd, 454 U.S. 1025 (1981), rejected on standing grounds a U.S. senator's challenge to a judicial appointment, even though an Act of Congress specifically gave "[a]ny Member of Congress" the right to bring such a suit challenging the particular appointment. Id, at 266 n.1. After concluding that the plaintiff lacked standing bccause of lack of injury, the court held that the language of the statute could not alter that conclusion: "It is difficult to see how this statute may, consistent with article III, confer upon a senator or member of the House of Representatives a 'right' to seek a decision from a federal court that such a senator or member of the Housc would otherwise be powerless to procure." Id. at 271 . 
On the other hand, a holding that Congress may override the injury limitation of Article III would have been both remarkable and particularly unfortunate in Defenders, because there is no indication that Congress embarked on such an ambitious undertaking when it enacted the Endangered Species Act. The citizen suit provision does indeed authorize "any person" to bring suit and defines "person" in a manner that includes organizations such as the plaintiff in Defenders. ${ }^{49}$ Under normal principles of statutory interpretation, however, such a broad statutory grant should be construed in a manner consistent with constitutional limitations, including the Article III limitation that only those who suffer actual injury have standing to sue. ${ }^{50}$ Congress made this limitation explicit in other citizen suit provisions, which is why-contrary to the concerns Professor Pierce expresses ${ }^{51}$ - those other provisions do not even pose the conceptual problem presented here. ${ }^{52} \mathrm{Al}-$ though the citizen suit provision in the Act lacks such an explicit limitation, there is no indication that Congress thought it was departing from the usual citizen suit pattern to test the limits of its constitutional powers. ${ }^{53}$

49. 16 U.S.C. $\$ 1540(\mathrm{~g})(1)$ (1988); 16 U.S.C.A. $\$ 1532$ (13) (West Supp. 1993).

50. See, e.g., Edward J. DeBartolo Corp. v. Florida Gulf Coast Bldg. and Constr. Trades Council, 485 U.S. 568, 575 (1988); NLRB v. Catholic Bishop of Chicago, 440 U.S. 490, 499-501 (1979).

51. Pierce, supra note 5 , at $1188-89$.

52. For example, the citizen suit provision in the Clean Water Act authorizes "any citizen" to bring suit and defines "citizen" as "a person or persons having an interest which is or may be adversely affected." 33 U.S.C. $\S 1365(\mathrm{~g})$ (1988). As the Court explained in Middlesex County Sewerage Auth. v. National Sea Claminers Ass'n, 453 U.S. 1 (1981), "[i]t is clear from the Senate Conference Report that this phrase was intended by Congress to allow suits by all persons possessing standing under this Court's decision in Sierra Club v. Morton, 405 U.S. 727 (1972)." Id. at 16; see Gwaltney of Smithfield, Lid. v. Chesapeake Bay Found., 484 U.S. 49, 70-71 (1987) (Scalia, J., concurring in part and concurring in the judgment) (finding citizen suit provision of Clean Water Act embodies constitutional requirement of injury).

53. See Defenders of Wildlife v. Hodel, 851 F.2d 1035, 1045 (8th Cir. 1988) (Bowman, J., dissenting) (declining "to attribute to Congress 1 he unexpressed intent to dispense with standing requirements entirely .... Surely Congress did not intend this provision to be read in a vacuun, without regard to constitutional linitations"), rev'd sub nom. Lujan v. Defenders of Wildlife, $112 \mathrm{~S}$. Ct. 2130 (1992). In Defenders, the government argued that the case did not even arise under the citizen suit provision. That provision authorizes suits against those "alleged to be in violation" of the Endangered Species Act, 16 U.S.C. $\& 1540(\mathrm{~g})(1)(\mathrm{A})(1988)$, and an erroneous interpretation of the Act-the gravamen of the plaintiff's complaint in Defenders-is not itself a "violation" of the Act. The suit is instead properly viewed as arising under the Administrative Procedure Act, which limits suit to those who are "adversely affected or aggrieved" by the action in 
The Court has recognized that the requisite Article III injury "may exist solely by virtue of 'statutes creating legal rights, the invasion of which creates standing." "54 The Court in Defenders explained that its prior cases applying this principle were consistent with the injury in fact requirement, because in those cases the statutes in question elevated injuries that were not previously legally cognizable to the status of legally enforceable rights. ${ }^{55}$ The Endangered Species Act, however, is not a "statute[] creating legal rights." ${ }^{\text {T6 }}$ The substantive provision at issue in Defenders simply requires consultation among federal agencies; it does not by its terms confer legal rights on private persons. ${ }^{57}$ Nor does the citizen suit provision ${ }^{58}$ create rights the invasion of which creates standing; it simply authorizes suit to vindicate rights which must be found elsewhere. ${ }^{59}$ As stated above, the consultation provisions which the plaintiff in Defenders invoked create no such rights. ${ }^{60}$

question-i.e., those whose injury "falls within the 'zone of interests' sought to be protected by statutory provisions whose violation forms the legal basis for his complaint." 5 U.S.C. \& 702 (1988); see Lujan v. National Wildlife Fed'n, 497 U.S. 871, 883 (1990).

54. Defenders, 112 S. Ct. at 2145 (quoting Warth v. Seldin, 422 U.S. 490,500 (1975)); see also Linda R.S. v. Richard D., 410 U.S. 614, 617 n.3 (1973).

55. See Defenders, 112 S. Ct. at 2145-46 (discussing Trafficante v. Metropolitan Life Ins. Co., 409 U.S. 205 (1972) and Hardin v. Kentucky Utils. Co., 390 U.S. 1 (1968)).

56. See id. at 2145 (quoting Warth, 422 U.S. at 500 (quoting Linda R.S., 410 U.S. at 617 n.3)).

57. 16 U.S.C. § 1536(a)(2) (1988).

58. Id. \& $1540(\mathrm{~g})$.

59. See Defenders, 112 S. Ct. at 2147 (Kennedy and Souter, JJ., concurring in part and concurring in the judgment) (stating that citizen suit provision "does not of its own force establish that there is an injury in 'any person' by virtue of 'any violation' "); see also Valley Forge Christian College v. Americans United for Separation of Church \& State, 454 U.S. 464, 488 n.24 (1982) (noting that Administrative Procedure Act provision authorizing any person "adversely affected or aggrieved" by agency action to bring suit does not create legal rights).

60. Contrary to Professor Pierce's concern, nothing in Defenders casts doubt on the constitutionatity of the Freedom of Information Act (FOIA). Pierce, supra note 5, at 1189-90. Under FOIA, every person is given a right of access to nonexempt government documents. When an agency wrongfully denies an individual's FOIA request, that particular individual has suffered injury in fact under Article III and has standing to sue in federal court to redress that injury. FOIA authorizes just such a suit. Another individual who has not made a disclosure request, and therefore has not suffered a wrongful denial, has not been injured and does not have standing to suc, even if he would like to have access to the same documents. See Public Citizen v. Unitcd States Dep't of Justice, 491 U.S. 440, 449-50 (1989) (Parties establish standing under FOIA by showing that "they sought and were denied specific agency records .... The . . fact that numerous other citizens might request the same information... [does not mean] that those who have been denied access do not possess a sufficient basis to sue."). 
Recognizing that Article III is a constraint on Congress's power to assign matters to the federal courts is not the assault on "legislative supremacy" that Professor Pierce bemoans. ${ }^{61}$ In the first place, the legislature is not supreme in our system of government-the Constitution is. Holding a statute unconstitutional because it transgresses Article III is nothing more than a recognition of that principle-a principle the Supreme Court has felt obligated to defend since the first case holding an Act of Congress unconstitutional under Article III. That case was, of course, Marbury $v$. Madison, ${ }^{62}$ and although at the time some regarded Chief Justice Marshall's opinion as an assault on legislative supremacy, it since has been recognized as the cornerstone of the constitutional rule of law.

More specifically, it is worth noting that a standing decision such as Defenders in no way inhibits Congress from pursuing substantive objectives. When a court finds that an Act of Congress violates, for example, the First Amendment, "legislative supremacy" is indeed restricted, for Congress cannot do what it sought to do. A standing decision simply means that Congress cannot enlist the federal courts in its enterprise-and even then, it cannot do so only because the specific plaintiff invoking the courts' authority lacks the requisite injury. Congress is perfectly free to cut off funding for the Aswan Dam or Mahaweli River projects if it concludes those projects threaten endangered species. It also can exercise its oversight power if it believes agencies are not consulting adequately about such effects. The one thing it may not do is ask the courts in effect to exercise such oversight responsibility at the behest of any John Q. Public who happens to be interested in the issue.

Viewed in this light, standing-like other doctrines of judicial self-restraint-compels the other branches of government to do a better job in carrying out their responsibilities under the Constitution. By properly contenting itself with the decision of actual cases or controversies at the instance of someone suffering distinct and palpable injury, the judiciary leaves for the political branches the generalized grievances that are their responsibility under the Constitution. Far from an assault on the other branches, this is an in-

61. Pierce, supra note 5, at 1201.

62. 5 U.S. (1 Cranch) 137 (1803). 
sistence that they are supreme within their respective spheres, protected from intrusion-however welcome or invited-of the judiciary.

Separation of powers is a zero-sum game. If one branch unconstitutionally aggrandizes itself, it is at the expense of one of the other branches. Dean Nichol loses sight of this reality in criticizing Justice Scalia's invocation of the "take Care" clause of Article II. According to Dean Nichol, "a challenged legislative or judicial action either unconstitutionally abrogates executive power or it does not. It should make little difference what sort of plaintiff seeks to trigger the incursion." ${ }^{63}$ The Article III standing requirement that the judiciary act only at the behest of a plaintiff suffering injury in fact, however, ensures that the court is carrying out its function of deciding a case or controversy, rather than fulfilling the executive's responsibility of taking care that the laws be faithfully executed. We accept the judiciary's displacement of the democratically elected branches when necessary to decide an actual case; Dean Nichol would seem to make a virtue of this necessity by jettisoning the injury in fact requirement for Article III standing.

Standing is an apolitical limitation on judicial power. It restricts the right of conservative public interest groups to challenge liberal agency action or inaction, just as it restricts the right of liberal public interest groups to challenge conservative agency action or inaction. ${ }^{64}$ It precludes Congress from assigning a right to sue to those without injury whether the statutory interest sought to be judicially enforced is perceived as liberal or conservative. The relatively recent growth of conservative public interest groups, and the even more recent change in presidential administrations, should set the stage for rethinking the facile assumption that standing cloaks a political agenda. It does derive from and promote a conception that judicial power is properly limited in a democratic society. That leaves greater responsibility to the po-

63. See Nichol, supra note 4, at 1163-64.

64. As one commentator has noted, "courts favorably disposed toward the New Deal reformation developed doctrines of standing, ripeness, and reviewability largely to insulate agency decisions from judicial intervention. Such doctrines were used enthusiastically by judges associated with the progressive movement and the New Deal, most prominently Justices Brandeis and Frankfurter .... This view has enjoyed a kind of renaissance in recent years, though from judges with a quite different political orientation." Sunstcin, supra note 23 , at 1437-38. 
litical branches of government-however they are inclined. To the extent that is a political agenda, it is the one the Framers enshrined in the Constitution.

Professor Pierce makes a subtler point. $\mathrm{He}$ argues that the Court's standing jurisprudence favors regulated entities over those who benefit from regulation; because the former can readily show concrete injury while the latter will have a more difficult time doing so. ${ }^{65}$ The extent to which this may distort judicial intervention in the administrative process, however, should not be exaggerated. ${ }^{66}$ The Court has not revisited the proposition that "[a]esthetic and environmental well-being, like economic well-being, are important ingredients of the quality of life in our society, and the fact that particular environmental interests are shared by the many rather than the few does not make them less deserving of legal protection through the judicial process." 67

What the Court has done is rule, for example, that a plaintiff who alleges only that she uses land "in the vicinity of" a $2,000,000$-acre area-only 4500 acres of which are affected by the challenged action-has not adequately shown that she is among those injured by the action, ${ }^{68}$ and that a plaintiff who alleges. she might visit certain areas sometime in the future has not shown injury from an agency's failure to consult about possible effects of funding decisions on endangered species in that area. ${ }^{69}$ Far from indicating "a transformation in the law of standing," sions are a natural response to efforts to render the standing limitations meaningless.

The consequences of accepting the proposition that injury in fact is not an Article III limitation on federal court jurisdiction

65. Pierce, supra note 5, at 1194-95.

66. See Sunstein, supra note 23 , at 1478 (noting "any such limitations (on congressional power to grant standing] should come up infrequently even if they exist").

67. Sierra Club v. Morton, 405 U.S. 727, 734 (1972). Relying on "liberal federal pleading standards," the Court also has allowed plaintiffs to amend complaints found to contain inadequate allegations of injury. Havens Realty Corp. v. Coleman, 455 U.S. 363, 377-78 (1982). This is not to say that plaintiffs may continually reformulate their theory of standing. See Center for Auto Safety v. Thomas, 847 F.2d 843, 877 n.2 (D.C. Cir.) (en banc) (Silberman, J.) ("A lawsuit is not a continuing dialogue with the judiciary in which a party may try different theories of standing until one succeeds."), reh'g granted and opinion vacated, 856 F.2d 1557 (D.C. Cir. 1988).

68. See Lujan v. National Wildlife Fed'n, 497 U.S. 871, 886-87, 889 (1990).

69. Lujan v. Defenders of Wildlife, 112 S. Ct. 2130, 2138 (1992).

70. Nichol, supra note 4, at 1142. 
ought to give one pause. Under such a view, Congress would be free to pass a statute conferring certain responsibilities on an agency with no more guidance than that which the extremely broad delegation doctrine requires. ${ }^{71}$ Congress also could specify that any person who wants to sue the agency in federal court may do so if he believes the agency is not living up to its mandate. Such a state of affairs would transform the courts into ombudsmen of the administrative bureaucracy, a role for which they are ill-suited both institutionally and as a matter of democratic theory. The Court's recognition that injury in fact is a requirement of Article III ensures that the courts will more properly remain concerned with tasks that are, in Madison's words, "of a Judiciary nature."72

71. The Court has explained that Congress need do no more than lay down an "intelligible principle" to satisfy the nondelegation doctrine. See Touby v. United States, 111 S. Ct. 1752, 1756 (1991); Skinner v. Mid-America Pipeline Co., 490 U.S. 212, $218-19$ (1989); see also Thomas W. Merrill, The Constitutional Principle of Separation of Powers, 1991 SUP. CT. REV. 225, $246-47$.

72. 2 RECORDS, supra note 18 , at 430 . 